\title{
SOCIAL CONDITION OF HOLY PLACE IN WEST INDIA: ACCUMULATION FROM SIGNATURE (C. 11TH TO THIRTEENTH CENTURY CE)
}

\author{
Narayana Swami G.
}

Department Of History , Karnatak University Dharwad,India

\section{ABSTRACT}

The sanctuary means one's convictions. Its primary highlights have likewise stood out for one. George Michell, Stella Kramrisch, Krishna Deva and some different researchers have examined the 'which means and structures', expressive, strict and otherworldly meaning of the sanctuary. We additionally discover the sanctuary being referenced regarding a comprehension of early Indian political, monetary and socio-strict exercises in north and south India. Furthermore, the sanctuary is additionally known to have been related with social exhibitions like dramatization and so on Luckily, in such manner we have various epigraphic records from west India, especially from Rajasthan and Gujarat, which point out the social part of the sanctuary during the c. 11th to thirteenth century CE. The current article looks to consider this part of the sanctuary.

KEYWORDS:- West India, sanctuary, social angle, engravings, epigraphic record

\section{INTRODUCTION}

It shows up from early Indian history up to c.1300 CE that people have utilized both land and water to satisfy the necessaries of life. This is upheld by archaeological confirmations Chakrabarti 1998 and verifiable encounters Chakravarti 2012 through hundreds of years from as right on time as the times of the preliterate stage in early India. From these confirmations we discover that individuals have related their exercises to various sections of the earth. These are the bumpy territory, the riverine region, the agrarian region, the littoral region, the peaceful region or even the crude region Chattopadhyaya 2004:40. Hence they have changed their actual scene as and when they have felt it important to do. In doing this, individuals have assembled, as we learn, different encounters regarding their associations with their environmental factors through ages. In this association we like to recommend that people have created two fundamental feelings. The first is identified with the possibility of causation associated with spirits, divinities or forces of nature in the universe and the second is worried about the possibility of a spirit alluding to the post-existence Hastings 1956: 676. We are informed that it is just Knowledge Brahmavidyā that can guarantee discharge mokșa for people from a wide range of servitude. Along these lines we go to 'the tenet of immigration sansāra.' According to the convention, after death a man returns to this 
CURRENT RESEARCH JOURNAL OF HISTORY 2(5): 23-25, May 2021

DOI: https://doi.org/10.37547/history-crjh-02-05-07

ISSN 2767-472X

(C)2021 Master Journals

\section{Crossref dof 80 Google}

Accepted 22 ${ }^{\text {th }}$ May, 2021 \& Published 29th May, 2021

world. In this association we track down that the activities karma of a person influence their resurrection Michell 1976: 15. We discover that there are approaches to definite delivery and one of the ways is journey. It is accepted that journey guarantees discharge for the individuals who have controlled their brains and activities. Consequently we approach the event of consecrated spots tīrthakșetra like Dvārakā, Badri and so forth Bhardwaj 1972. We are additionally informed that in these spots divine beings consistently stay. One can get last delivery mokșa from a particularly consecrated spot Kramrisch 1997: 3-3 . A correspondence with heavenly nature is hence settled. Such contact is set up through one's convictions. We track down that the sanctuary as a connection between people and divine beings addresses the human journey for contact with godlikeness Michell 1976: 62 . Accordingly the sanctuary implies their convictions. Thusly one trademark highlight of a consecrated spot might be the sanctuary Kramrisch 1997: 6 Devālaya . The underlying highlights of the sanctuary are notable to have pulled in the consideration of the researcher.

\section{Discussion}

We are informed that a Sanskrit play called Karṇasundarī Nātikā by Bihlaṇa was acted in the sanctuary of Ādinātha. The show was created during the rule time of Karna of VS 1112-1151 CE 1064-1092. We are additionally informed that individuals used to see such social execution at the sanctuary. Presumably some of them comprehended the feeling of the show. Such social execution was hung on happy event. Sandesara: 17. We gain from the Arthuna close to Banswara lat. 241 south, long. 741 east, Rajasthan engraving of the Paramāra lord
Chāmuṇuarāja of Vikrama-Samivat 1137 CE 1078 that the two celebrations for the benefit of the Mandaleśa Siva sanctuary were held; one was the Caitra March-April celebration Caitryām and the different was 'the celebration of the consecrated string' Pavitryām Barnett 1981: 285-283, 301, 308. We are informed that the two such celebrations Caitra and Pavitraiwere yearly celebrated in numerous South Indian sanctuaries Narasimhachar 1908: 52 .The sanctuary's investment in the celebrations was upheld by the broker. Now we may allude to another social exhibition of the sanctuary. Regarding the parade related celebration Yātrāmahotsava of Mahāvīra a Sanskrit dramatization named Moharājaparājaya success on lord Moha or obliviousness by Yaśahpāla was acted at the sanctuary developed by the Chaulukya ruler Kumārapāla of VS 12011228 CE 1142-1170. The play depicts that Kumārapāla was changed over to Jainism. He was disallowed from creature slaughtering and kept from taking properties of the individuals who passed on without beneficiaries. The dramatization was arranged to show that the Jain religion had a part in the guideline of the realm. Sandesara: 14.

\section{Conclusion}

From the conversation made that far creates the impression that the sanctuary other than its compositional significance was a valuable medium to the ruler to solidify his force and authority. The sanctuary gave the space which the merchant found supportive to carry on his financial exercises. Accordingly the political and financial parts of the sanctuary are notable. Aside from these the sanctuary as a social organization additionally assumed a social part and imparted tasteful sense to the everyday citizens in south 
CURRENT RESEARCH JOURNAL OF HISTORY 2(5): 23-25, May 2021

DOI: https://doi.org/10.37547/history-crjh-02-05-07

ISSN 2767-472X

(C)2021 Master Journals

Crosser do) 81 Google

Accepted 22 ${ }^{\text {th }}$ May, 2021 \& Published 29th May, 2021

India, yet additionally in west India.

\section{REFERENCES}

1. Beneth, deniel D. 1983. 'Arthuna Inscription of the Paramara Chamundaraja Vikrama-Samvat 1137', Epigraphia Indica XIV (21): 294-297, 301, 308.

2. Bhuwanishankar, v. R. 1913 'Anāvāā stone engraving of Sārangadeva Vikrama Samvat 1349', Indian Antiquary:21-22.

3. Bhuwanishankar, v. j. 1982. 'Lālrāī Stone Inscription of Lākhaṇapāla and Abhayapāla; Vikrama Samvat 1234', Epigraphia Indica XI (XVI): 55-52.

4. Bhuwanishankar, v.j.. 1981. 'The Chahamanas of Marwar', Epigraphia Indica XI(XIX): 55-56.

5. vasudeva r.p.s.. 1981. 'Bhinmal Stone Inscription of Udayasimhadeva; [Vikrama] Samvat 1307', Epigraphia Indica XI (XX):56-58.

6. Bhuwanishankar, v.j.. 1974. Hindu Places of Pilgrimage in India (A Study in Cultural Geography). Berkeley: University of California Press 